\title{
Minority Students and the Legal Curriculum: An Experiment at Berkeley
}

\author{
Richard Delgado*
}

This Article describes the difficulties and rewards of offering a law school course specifically focused on legal issues facing Mexican Americans. Such a course, the author concludes, can be successfully offered even with extremely limited resources, and is especially valuable both in providing minority students with experience in legal writing and in conveying the relationship between the traditional law school curriculum and the problems of the barrio.

In the fall of 1973, a student-initiated course entitled "Legal Problems of Spanish-Speaking People in California and the Southwest" was offered at Boalt Hall. ${ }^{1}$ A two-unit seminar open to all secondand third-year law students the course was "taught" by a series of visiting lecturers, assisted by a faculty sponsor ${ }^{2}$ and a student coordinator. ${ }^{3}$ Purposely designed as an experiment, the low-budget ${ }^{4}$ course succeeded in raising significant questions about the role of courses tailored to the interests and problems of ethnic minorities, the usefulness of student-initiated courses, and the utilization of resource personnel to enrich the content of courses in law.

* Assistant Professor of Law (Designate), University of Washington; J.D. University of California at Berkeley, 1974; A.B. University of Washington, 1960. As a third-year student, Mr. Delgado served as initiator and student coordinator of the experimental course described herein.

1. Two years earlier, in the spring of 1972, a related course entitled "Legal Developinents Affecting the Mexican-American" was offered by a visiting lecturer, Cruz Reynoso, who also taught a similar course at the U.C.L.A. law school. The earlier course, however, was not repeated at Boalt Hall.

2. The faculty sponsor was Kenneth Phillips, Lecturer in Law, Associate Director of the Earl Warren Legal Institute, and Director of the Institute's National Housing \& Econoınic Developınent Law Project. Mr. Phillips is a nationally recognized authority in the areas of housing law and economic development.

3. The student coordinator was Richard Delgado, a third-year Chicano law student, now Assistant Professor of Law (Designate) Umiversity of Washington.

4. Immediate costs to the law school were under $\$ 1100$. The main expenses were for copying materials and providing a salary for the student coordinator, who worked on a half-time basis during the summer preceeding the opening of the course. The above figure may be slightly misleading, however, in that it does not include an allowance for the value of the faculty sponsor's time, which he donated in addition to his normal administrative and teaching load. 
The purposes of this Article are, first, to describe the development and implementation of the course, and second, to address the problems and issues likely to arise when similar courses are offered in the future. It is hoped that after evaluating the successes and failures of this class it will be possible to design better courses of this nature, and that other law students and teachers will be stimulated to consider the values to be gained from courses that focus on the legal problems of sectors of the population that have hitherto been virtually ignored in legal curricula. ${ }^{5}$

\section{DEVELOPMENT OF THE COURSE}

Discussion of a course in Mexican-American legal issues began at Berkeley in the winter of 1972. A symposium issue on migrancy and bilimgualism had been planned by the California Law Review after preliminary research had revealed a remarkable dearth of books and articles on such issues. It was thought that an issue devoted to these and related topics could generate increased interest and awareness on the part of the legal community. When it became evident that it would be impossible to produce the symposium because of a lack of expertise and manpower, a course was proposed which would cover much the same ground and which, it was hoped, would result in student-written papers that would augment the small body of hiterature on Chicanorelated legal problems. ${ }^{\circ}$

At the same time it was hoped that the course would provide an opportumity for Mexican-American students at Boalt to gain experience in writing for legal publication. Boalt Hall's student population included approximately 80 Chicano students, ${ }^{7}$ most of whom were ad-

5. A canvassing of recent catalogs of major American law schools reveals that a substantial number offer a course on poverty law. See, e.g., the official bulletins of the following schools of law: Arizona State University, Columbia University, U.C.L.A., Duke University, University of Denver, Georgetown University, Harvard University, University of Maryland, University of Minnesota, University of Michigan, University of New Mexico, University of California at Berkeley, University of Virginia. A smaller number offer a course on American Indian law. See, e.g., official bulletins of Arizona State University, U.C.L.A., University of Colorado, University of Minnesota, University of New Mexico. A substantial number offer courses ou the problens of black Americans. See, e.g., catalogs of Columbia University (African Law), University of California at Berkeley (Slavery), U.C.L.A. (Civil Rights, with an emphasis on discrimination against blacks), Harvard Umiversity (Slavery \& Racial Issues), University of Pennsylvania, University of Maryland, Rutgers University. Courses in the legal problems of Spanish-speaking people have been offered at Berkeley, U.C.L.A., and Georgetown University.

6: The term "Chicano" is often used to refer to persons of Mexican-American descent. It is so used herein.

7. Boalt Hall has had in effect an affirmative admissions policy for racial 
mitted under a special admissions program and many of whom suffered some degree of language handicap. Despite this, the school had not offered supplementary writing instruction apart from the brief treatment provided by teaching associates in connection with the first-year moot court program. Many Chicano students at Boalt had voiced dissatisfaction over the lack of instruction in legal writing and had pushed for the institution of special programs designed to assist them to acquire the skills of legal writing. As a partial response, it was proposed that students in the course be given an opportunity to work with law review editors in the development of their papers in order to ensure, so far as possible, that the final product would be publishable, and to afford the student writers the benefit of the rigorous criticism and editing normally available only to law review nembers.

In addition, other considerations contributed to the particular need for such a course at the law school. Students from ethnic minorities constituted approximately 25 percent of the student body, yet many faculty members still did not seen to appreciate fully the difficulties many minority students, particularly Chicanos and Native Americans, ${ }^{8}$ suffer in trying to grasp the relevance of standard law school courses to their own areas of interest. To the minority student, the problems and cases studied in their classes often seem to revolve around the legal problems of either giant corporations or wealthy individuals with little relevance to the poor community and the barrio. Few professors take the time in class to demonstrate the relationship of the cases in the textbook to the concerns of the farm laborer or barrio resident, and the student is left to discover on his or her own the applioability of the course material to the concerns of the poor community.

Moreover, "Chicano law" has certain dimensions that set it apart substantively from the material studied in conventional first- and second-year law courses. The legal problems of Spanish-speaking people are colored by such factors as bilingualism and English language handicap, migrancy, and poverty that seldom occur-at least in coinbination-anywhere else. Failure of the curriculum to address these problems compounds the Chicano student's sense of unreality. Unable to see how the material assigned relates to his or her personal and professional aspirations, the student may conclude that it is impossible to serve the cominunity effectively as a lawyer. Some of these students

minorities for a number of years. Presently, blacks, Chicanos, and Native Americans constitute about 25 percent of the student body.

8. All minority students probably experience this difficulty to some extent, but the problem appears to be most acute for Mexican-Americans and Native Americans who, in the main, arrive at law school with substantial educational and linguistic handicaps. See, e.g., Note, Equal Educational Opportunities for Chicanos and Indians, 1 New MeX. L. Rev. 335 (1971). 
may drop out of law school and seek direct involvement in community activities; others may remain but gradually change their career plans, opting for corporate or commercial practice. For these students, exposure to attorneys of their own ethnic background who are litigating cases relating to their own community's problems can prove to be a strongly reinforcing experience. For other students, discovering that the nuaterial presented in standard law courses can be applied to the practical problenis of minority people can do much to overcome the disaffection that so often characterizes the second and third years of law study. ${ }^{9}$

A planning group was formed to prepare a course proposal. The group consisted of the editor-in-chief of the California Law Review, the chairman of La Raza Law Students Association, the faculty sponsor, and the student coordinator. This group was joined a short time later by the Deputy Director of California Rural Legal Assistance, ${ }^{10}$ who participated in the meetings and who later proved extremely helpful in locating resource personnel and speakers.

Gradually, the fornat of a two-seniester sequence was developed. The first semester would be devoted to lectures on various subjects to be selected by the students theinselves. Early in the semester each student would select a topic for his or her course paper and would begin writing, assisted by a law review editor. At the end of the seniester, the papers would be evaluated and students whose papers showed particular pronrise would be given the opportunity to enroll for a second semester of individual study in which they would work toward preparing the manuscripts for submission to a legal journal.

Once the basic structure of the course had been decided upon, the coordinator began selecting the problem areas that the course would cover. Chicano students in the first- and second-year classes were canvassed for suggestions since it was expected that these students would constitute the major portion of the class's enrollment. Suggestions received ranged from general topics sucli as civil rights to more narrow problems sucli as border searches. The suggestions were organized into 11 major subject areas: the Spanish-speaking community, the Chicano attorney, political representation, economic liberation, employment, farm labor problenis, lousing, immigration, education, Spanish-speakers and the criminal justice systen, and welfare. ${ }^{11}$ Each topic would form the focus of one week's study. The first few lectures would be devoted to broad background material, covering such issues

9. Cf. Stone, Legal Education on the Couch, 85 HARv. L. Rev. 392, 426 (1971).

10. The Deputy Director, Jose Martinez, is a recent Boalt Hall graduate.

11. For a more detailed outline of the subject areas see the appendix at the conclusion of this Article. 
as the nature and composition of the Spanish-speaking community and the role of the attorney in providing legal services to that community. The lectures that followed would deal with narrower areas of substantive law. Each of these lectures would begin with an overview of the statutory, administrative, and case law relating to the subject area in question, and then proceed to a discussion of specific problems relevant to the minority community. Each meeting would include explict consideration of the role of the attorney in providing legal services, and of typical career patterns in various kinds of work. The closing sessions would be devoted to oral presentations and the discussion of student papers.

A proposal was submitted to the school's curriculuin committee. The law school quickly approved it and provided a moderate stipend ${ }^{12}$ to permit the coordinator to work half-time during the summer, locating and preparing course materials and contacting potential speakers.

The task of finding guest lecturers was surprisingly easy. Local legal services offices, California Rural Legal Assistance, and the faculty of the Berkeley campus proved to be ready sources for expert speakers. The list of speakers included three members of the law school faculty, ${ }^{13}$ the Deputy Director of C.R.L.A., ${ }^{14}$ a California State Assemblyman, ${ }^{15}$ an economist, ${ }^{16}$ several practicing attorneys, ${ }^{17}$ and a university professor of Chicano Studies. ${ }^{18}$ Most of the persons contacted agreed to come without the inducement of an honorarium.

After a speaker accepted an invitation, he or she was asked to submit suggestions for reading materials, which were gathered over the summer and edited. Bibliographies of each subject area were prepared, and the materials were incorporated into a 600-page "textbook,"10 containing appellate opinions, articles, statutes, and legislative inemoranda.

12. One thousand dollars was made available from a special law school fund for this purpose.

13. Professor John Coons conducted the seminar on education. Professor Henry Ramsay led the session on the criminal justice system and minority communities. The faculty sponsor, Kenneth Phillips, led the meeting on housing law and policy.

14. Jose Martinez, Deputy Director of California Rural Legal Assistance, led a seminar on the role of the Chicano attorney.

15. California State Assemblyman Richard Alatorre gave a presentation on Chicanos and political power.

16. Arthur Blaustein led the class on the subject of economic development in minority communities.

17. The attorneys were Fred Altshuler (CRLA), Jerry Cohen (United Farm Workers Union), Donald Unger (immigration law attorney), and Ralph Abascal (San Francisco Neighborhood Legal Assistance Foundation).

18. Professor Velia Garcia-Hancock, of the University of California Chicano Studies Department, gave the mitial lecture on the Chicano community.

19. Partial sets of these materials may be ordered from the law school bookstore at the University of California for a price of $\$ 6.95$ (single copies only). 


\section{IMPLEMENTATION AND APPROACH}

\section{A. Enrollment}

Hoping to preserve an intimate, seminar-like setting, the planners intended to limit enrollment to between 15 and 25 students. Notices were mailed to every first- and second-year Chicano student, and shortly before fall registration, announcements were placed on bulletin boards in the school of law. A dozen students enrolled, all but one of Spanish-American extraction. Two subsequently dropped the course because of conflicts with other courses. ${ }^{20}$ The class also included several students who attended all the meetings but did not officially enroll. In addition, a number of auditors attended selected class sessions, depending on the appeal of the subject and the drawing power of the speaker. The highest attendance at a smgle class-farm labor problems-was 50 students.

Enrollment might have been larger had it not been for certain difficulties. Some Chicano students reported that they had wanted to enroll but had hesitated to do so because of doubts that the course would help prepare them for such concrete goals as passing the state bar examination. ${ }^{21} \mathrm{~A}$ few were discouraged by the writing requirement, despite our assurance of the availability of assistance from the faculty sponsor and student editors. Confusion over the law school's credit requirements deterred other students from enrolling. The late hour posed a problein for a few.

\section{B. Lectures}

The planners set out deliberately to avoid a formal, Socratic style of presentation in favor of a more flexible format consisting of an initial presentation by a guest speaker followed by questions and discussion. The emphasis on a low-keyed approach caused some confusion at first. At some of the initial meetings it was evident that a few students had failed to prepare for the lecture; others neglected to bring the assigned materials to class. Others treated the first few meetings as socio-political "rap sessions." On the whole, howeyer, these tendencies were adequately controlled by peer pressure and largely disappeared after the first few weeks.

20. To avoid conflict with other classes, the late afternoon hour of 4 o'clock was chosen. At the last minute, however, the school added a course on the role of the lawyer as negotiator, which proved to be very popular with the students and created conflicts for a number of Chicano students who wanted to enroll in both courses.

21. This fear is not necessarily an unrealistic one. Minority graduates from Boalt have tended to fare more poorly than its other graduates on the California bar examination. 
The lectures themselves were of uniformly high quality and amply fulfilled the hope that practitioners who are intimately involved in litigating issues of concern to Mexican American people could contribute significantly to the education of law students. While all the lecturers acquitted themselves with distinction, perhaps the most pleasant surprise was the performance of the practicing attorneys. Drawn from a variety of poverty and public interest law offices in Northern California, these young lawyers commanded the immediate attention of the students and often provoked discussions lasting well past the scheduled hour for adjournment.

In several of the lectures a difficult choice was presented over whether to emphasize a broad coverage of the topic or a narrower analysis of specific cases and problems. The planners and lecturers decided in favor of breadth of discussion. It was felt that one of the main functions of the course was to provide an introduction to a wide range of subjects that the students would need to know something about but would not be able to fit into their programs because of the pressures of time and course scheduling. ${ }^{22}$ They also wanted to encourage the students to extrapolate and perceive connections between the material covered in standard law school courses and the problems confronting Spanish-speaking people. This could be done more effectively, it was felt, by selecting a number of broad subject areas rather than by concentrating on a few narrow issues.

Perhaps unaware of the objectives of the course, a few faculty members questioned the intellectual integrity of what they saw as a "survey" course, and others wondered whether the course contained anything that could not be gained from such standard law school courses as labor law and creditors' remedies. Both criticisms reflected the planners' failure to convey fully to the faculty the goals of the course and the special needs of the students.

\section{Student Writing}

Significant problems arose in connection with the Law Review's involvement in the course. After the first blush of enthusiasm had faded, the journal began to reconsider its institutional commitment to supply editorial assistance to the students enrolled in the course. Some Review members expressed concern that giving substantial support to these students could result in equal protection problems: if the journal lent its support to one group, how could it resist similar claims for assist-

22. Because of the limited amount of elective credit students may earn during their tenure in law school, few students are able to enroll in courses dealing in depth with each of the problem areas covered in this course. 
ance by other groups or individuals? ${ }^{23}$ It was eventually decided that Review members would devote their time to the course voluntarily and in their non-mstitutional capacities, a lawyerlike solution the net effect of which was largely to deprive the students of any significant editorial assistance in preparing their papers. ${ }^{24}$ Nonetheless, seven students completed their papers during the second semester.

\section{III}

\section{CRITIQUE From WITHIN}

A number of students, although expressing satisfaction with the quality of the seminars, complained that the overall structure was too fragmented. It would have been better, they felt, to focus more explicitly on a few recurring themes in each of the topics in order to give continuity and coherence to the course as a whole. Others, reflecting perhaps an internalization of conventional law school values, expressed disappointment that the visiting lecturers did not call upon students to recite cases or pose hypotheticals in standard Socratic style. Still others expressed regret that there had not been time for field trips-e.g. visits to cominunity legal offices or local courts.

While we were conscious of the problems posed by the wide variation in the knowledge and sophistication which the different students brought to the course, striking a balance between the familiar and the new was a problem that was never resolved to everyone's satisfaction. This problem was particularly troublesome in the introductory lectures since the material was obviously familiar to inany students.

Some students wanted more class discussion; others wanted to limit discussion in favor of devoting more time to the guest presentations. In the back of everyone's mind was the realization that 14 twohour sessions are simply insufficient to develop adequately such a large number of critically important problem areas. Nevertheless, many students commented that they had participated more in this class's discussions than in those of any other in law school. ${ }^{25}$

Other comments focused on the mechanical aspects of the course. A more favorable hour would have been desirable. Because the class

23. Some members even suggested that De Funis-style claims of "reverse discrimination" might be raised. See De Funis v. Odegaard, 82 Wash. 2d 11, 507 P.2d 1469, dismissed, 414 U.S. 1038 (1974).

24. Voluntarism failed to produce any offers of assistance during the critical first semester, when the students were drafting their papers. Three of the papers were selected by the faculty sponsor for further development during the second semester. Law review assistance was made available for each of those papers.

25. The implications of a law student's overcoming his reticence and volunteering to speak in class are important psychologically. See, e.g., J. OsBorne, The PAPER CHASB 43-47 (1973); Stone, Legal Education on the Couch, 85 HARv. L. REv. 392, 418 (1971). 
was scheduled late in the afternoon (in an attempt to pose the minimum conflict with other law school courses), students were sonnetimes tired and occasionally late, giving rise to a weekly dilemma whether to begin on time or wait for the latecouners. Nevertheless, interest remaimed high, regular class attendance was near 80 percent, and many meetings lasted far beyond the scheduled hour, the students and lecturer continumg their discussion over coffee in a nearby restaurant.

A final question that remained in the minds of some was whether the class amounted to anything more than an attractive, if potentially costly digression. Mimority students at any school of law quickly learn that success in law study involves a decision to devote themselves single-mindedly to acquiring the mode of thought of the dommant culture. $^{20}$ While most realize that to be meaningful to the mimority community everything that is learned in law school must be "translated" to come to terms with a set of conditions, problems, and clients different from those forming the context of the material presented, a great deal of uncertainty exists over when and how this translation is to be effected. Simultaneous translation risks fatal division of one's energies; translation delayed may never get done. So long as law and law teaching reflect the imterests of a society that is white and prosperous, mimority students will face this dilemma.

Still, the students felt that the course amply repaid their investment of time and energy, since it enabled thein to bring into focus their community and social concerns and their law school education. Many students commented that the close interaction with faculty members which the course permitted, the orientation toward problems which they, as students, felt to be of concern to their own professional futures, and the opportunity to take part in serious discussions in a low-keyed atmosphere lad been among the more stimulating and helpful experiences of their law school careers. A number of students remarked that the course had helped thein gam a less polarized understanding of the choice between traditional commercial practice and a law practice serving the more immediate needs of the mimority conımunity; they came to see eacl as responses to different emphases in a longrange program of community development.

26. That the laws and legal institutions of a given society tend to reflect the values and interests of the dominant social and economic groups is widely accepted by social scientists. See, e.g., C. BEARD, THE ECONOMIC INTERPRETATION OF THE CONSTTTUTION (1913); R. Dahrendorf, Class and Class Conflict IN Industrial SOciety 289-94 (1959) (discussing, at 294, the Marxian view that the legal system is only the "incarnation of the ideology of the ruling class"); Marx, Sociology of Politics, in K. MARx: Selected Writings in Sociology and Social Philosophy 223-26 (T. Bottomore, transl., 1956); C. Mills, The Power Elite (1956); M. Weber, The Protestant Ethic AND THE SpIRIT of CAPITALISM 25-26 (T. Parsons, transl., 1958). 


\section{IV}

\section{CONCLUSTONS}

At the end of the first year's experience, it is possible to draw a few tentative conclusions:

(1) Where volunteer speakers can be found, a course like the one described can be offered at a very low cost. The entire budget for the course amounted to less than $\$ 1100$, excluding the value of the faculty sponsor's time.

(2) A relatively successful course can be designed and staged largely by student volunteers or "coordinators," with relatively little investment of faculty or administrative time.

(3) The availability of such a course can have a highly beneficial psychological impact on minority students in the school.

(4) Where a faculty member with expertise in the topics to be covered is unavailable, resource persons from outside the school of law can carry out instructional functions in areas of their expertise in a highly competent inanner. Indeed, because of the scarcity of law teachers with such multifariour coinpetences, a format featuring guest speakers may well be the only way such a course can be successfully structured.

(5) Such a course can generate its own momentum and become self-perpetuating. At Boalt Hall a similar course is being offered during the 1974-75 academic year.

\section{Appendix: Legal Problems of Spanish-Speaking People in California and the Southwest-Course Outline}

Unit 1: The Spanish Community. Basic denographic, economic, and social characteristics of the Spanish-speaking population. Who are they and where do they live? Where are they froun? How do they earn a hiving? Attitudes of various Chicano communities toward thenselves and each other.

Unit 2: The Chicano Lawyer. What lawyers and legal institutions serve the Spanish-speaking commumity? Obstacles lying in the way of developing adequate nunbers of Chicano attorneys: law school admissions procedures, and the bar examination. Typical career patterns of Chicano attorneys. Role conflicts of the Spanish-speaking attorney.

Unit 3: Access to Pohtical Power. Achieving an effective voice within the two-party system. Apportionment and redistricting. Developinent of an effective Chicano lobbying force. Coalition politics as a means of influencing political parties. Legislative solutions to Chicano social problems. 
Unit 4: Economic Liberation. History and development of the community development corporation. Experience of Chicano communities with community-based development corporations. Farming cooperatives. Federal and state incentives for the development of minority busmess ventures.

Unit 5: Employment. Remedies for race-based employment discrimination. Affirmative action and employment preferences. Policy and constitutional aspects of affirmative hiring.

Unit 6: Farm Labor Problems. Development of unionism among farm workers. Bargaining with the grower. Use of secondary boycotts. Legislative relief for workers' problems. Would inclusion under the NRLA be in the workers' interests?

Unit 7: Housing. History of current landlord-tenant law. Development of federal involvement in subsidized housing for the poor. Failure of most programs to halt urban decay; need for new initiatives. Role of the attorney in representing tenant organization.

Unit 8: Immigration. Statutory basis for United States policies regulating admission of aliens. Deportation. Excluded classes. Status of illegal aliens. Border searclies and seizures.

Unit 9: Education. Sclool finance and the equal protection clause. Tracking and other forms of within-school classification. State policies regarding children of unigrant families. Bilingual education and the right to an "adequate" education.

Unit 10: Minority Communities \& the Criminal Justice Systent. Increasing the responsiveness of the police to the needs of ethnic minorities. Police review boards. Renedies for police harassment. Role of mimority prosecutors. Chicanos in court and in prison. Adequacy of the public defender system.

Unit 11: Welfare. Levels and types of welfare assistance. Legality and effect of residence requirments on Chicano migrant families. Practical and administrative problenıs in obtaining welfare relief for an indigent client. Effect of the language barrier on Chicano families in need of welfare benefits; right to bilingual notice. 